Article

\title{
An Analysis of the Performance Characteristics of Different Cylinder Temperatures for Ni-W and Ni-W-BN(h) Plated Piston Rings in an Air-Cooled Engine
}

\author{
Chih-Cheng Chou ${ }^{1,2, *}$, Pao-Chang Huang ${ }^{1,2, *(\mathbb{D})}$ and Huang-Bin Dai ${ }^{1}$
}

1 Department of Power Vehicle and Systems Engineering, Chung Cheng Institute of Technology, National Defense University, Taoyuan 33551, Taiwan; moondial1988@gmail.com

2 System Engineering and Technology Program, National Yang Ming Chiao Tung University, Hsinchu 30010, Taiwan

* Correspondence: cheng690606@gmail.com (C.-C.C.); abow213@gmail.com (P.-C.H.); Tel.: +886-3-380-9257 (ext. 260) (C.-C.C.); +886-3-380-9257 (ext. 262) (P.-C.H.)

Citation: Chou, C.-C.; Huang, P.-C.; Dai, H.-B. An Analysis of the Performance Characteristics of Different Cylinder Temperatures for Ni-W and Ni-W-BN(h) Plated Piston Rings in an Air-Cooled Engine. Energies 2022, 15, 1026. https:// doi.org/10.3390/en15031026

Academic Editor: Jude O. Iroh

Received: 17 December 2021

Accepted: 28 January 2022

Published: 29 January 2022

Publisher's Note: MDPI stays neutral with regard to jurisdictional claims in published maps and institutional affiliations.

Copyright: (c) 2022 by the authors. Licensee MDPI, Basel, Switzerland. This article is an open access article distributed under the terms and conditions of the Creative Commons Attribution (CC BY) license (https:// creativecommons.org/licenses/by/ $4.0 /)$.

\begin{abstract}
An engine must operate at an appropriate working temperature, the wear resistance of the engine parts must be increased, and frictional loss of energy must be reduced to increase performance and reduce exhaust pollution. This study determines the effect of cylinder temperature and different coatings for piston rings on engine characteristics. Ni-W alloy and Ni-W-BN(h) composite coatings are applied to the compression ring, and the dynamometer test is performed over $50 \mathrm{~h}$ using different operating parameters. The experimental data are analyzed by curve fitting for engine performance with cylinder temperature $\left(\mathrm{T}_{\mathrm{sc}}\right)$ and the concentration of exhaust pollution particles. The experimental results show that a Ni-W alloy plating increases the wear resistance of piston rings. A Ni-W$\mathrm{BN}(\mathrm{h})$ composite coating contains self-lubricating particles, which increases the wear resistance and lubricating properties. In terms of engine performance, $\mathrm{Ni}-\mathrm{W}-\mathrm{BN}(\mathrm{h})$ coated piston rings give the best brake mean effective pressure (BMEP) and fuel conversion efficiency $\left(\eta_{\mathrm{f}}\right)$, and low fuel consumption reduces $\mathrm{HC}$ and $\mathrm{CO}$ emissions. Therefore, $\mathrm{Ni}-\mathrm{W}-\mathrm{BN}(\mathrm{h})$ is the best coating material for a piston ring.
\end{abstract}

Keywords: piston ring coating; engine performance; cylinder temperature

\section{Introduction}

Due to environmental concerns, internal combustion engines must produce less polluting gas emissions. Increasing engine efficiency and power performance are important for developing internal combustion engines. The heat energy that is generated by the combustion of fuel in the cylinder is the energy that pushes the piston and produces work. If the engine cylinder operates at a proper working temperature, the fuel is completely burnt in a proper air-fuel ratio, maximum power is generated, and exhaust gases are reduced.

The cooling system for an air-cooled engine has a simple structure. Heat dissipation fins increase the efficiency of heat conduction. The control of the cylinder temperature has a significant effect on power and exhaust emissions. At an appropriate cylinder temperature, the lubricating oil film has an appropriate viscosity, so lubrication is increased, and wear is reduced. Power is increased, and there is greater mechanical protection [1].

Most of the mechanical loss in an engine is frictional loss. The frictional energy loss due to moving parts is an important element of these losses [2]. Speed, load, and torque are important parameters for engine performance, but frictional force changes little with engine load [3]. To increase the power output from an engine at a constant speed, friction must be reduced. Common engine sizes and power outputs usually involve empirical estimates of relative friction [4-6].

Some energy from fuel combustion in an engine is used to overcome friction. The indicated thermal efficiency of engines is about $40 \%$ to $50 \%$, with thermal brake efficiency usually about $30 \%$ [1]. The mechanical friction in an engine consumes about $4 \%$ to $15 \%$ of 
the total energy that is provided by the combustion of fuel [7]. To produce braking power, an engine must consume energy to overcome friction. Friction is a major cause of poor fuel efficiency for an engine.

Frictional energy loss for engine components accounts for a proportion of the total mechanical energy loss (including friction loss) for an engine [2]. The frictional loss due to a piston ring set and a piston skirt accounts for $67 \%$ of the total mechanical energy lost, the valve mechanism accounts for $16 \%$, and the bearing friction accounts for $12 \%$ of the total. At $100 \mathrm{~km} / \mathrm{h}$, the respective frictional losses are $65 \%, 9 \%$, and 15\%. Friction between the piston ring, the piston skirt, and the cylinder wall is the main contributor to frictional energy loss for an engine. The piston ring must produce a good seal to conduct heat away from the wall to reduce fuel consumption and emissions.

Engine piston rings often use a surface coating to improve the mechanical properties and allow better lubrication with oil. This reduces friction, increases wear resistance, produces a good seal, and prevents air leakage [8]. Chromium plating is often applied to piston rings [9]. To reduce environmental pollution that is caused by the commercial chromium-plating manufacturing process and to increase the corrosion resistance and wear resistance of high-temperature engine parts that incur friction, some studies use a Ni-based alloy or a composite coating for piston rings as a substitute for hexavalent chromium [10,11]. The study by Hirapara et al. [12] showed that molybdenum-coated piston rings produce a cooler exhaust gas and fewer exhaust gas particles $\left(\mathrm{NO}_{\mathrm{x}}, \mathrm{CO}, \mathrm{CO}_{2}\right.$, and $\left.\mathrm{HC}\right)$ than uncoated piston rings and increase braking power.

A nickel-based composite coating gives excellent temperature resistance, wear resistance, and corrosion resistance, so it is widely used as a surface treatment for engine components [13-15]. A heat-treated Ni-W coating has better mechanical properties and is thermally stable at high temperatures [16]. This study uses electrodeposited Ni-W alloy/BN(h) composite coatings to modify the surface of a common nodular cast iron piston ring [17] to decrease wear on engine components. The self-lubricating properties of the $\mathrm{BN}(\mathrm{h})[18]$ in the coating reduce friction and save energy, so less pollution escapes to the environment.

This study determines the cylinder temperature that gives the best performance for an air-cooled engine that uses nickel-based coatings piston rings. The mechanical properties of different coatings for piston rings are determined by the engine's operating characteristics using an eddy current dynamometer test. The emissions of hydrocarbons (HC) and carbon monoxide $(\mathrm{CO})$ from engines are measured.

\section{Experimental Procedure}

\subsection{Coating Preparation and Mechanical Properties}

The electrodeposition bath for the Ni-W alloy and Ni-W-BN(h) composite coating is shown in Table 1 . It contains nickel sulfate $\left(\mathrm{NiSO}_{4} \cdot 6 \mathrm{H}_{2} \mathrm{O}, 99 \%\right.$, Showa Co., Gyoda, Japan) at $0.06 \mathrm{~mol} / \mathrm{L}$, sodium tungstate $\left(\mathrm{Na}_{2} \mathrm{WO}_{4} \cdot 2 \mathrm{H}_{2} \mathrm{O}, 99 \%\right.$, Showa Co. $)$ at $0.14 \mathrm{~mol} / \mathrm{L}$, sodium citrate $\left(\mathrm{Na}_{3} \mathrm{C}_{6} \mathrm{H}_{5} \mathrm{O}_{7} \cdot 2 \mathrm{H}_{2} \mathrm{O}, 99 \%\right.$, Showa Co.) at $0.4 \mathrm{~mol} / \mathrm{L}$, ammonium chloride $(\mathrm{NH} 4 \mathrm{Cl}$, $99.5 \%$, Showa Co.) at $0.5 \mathrm{~mol} / \mathrm{L}$, hexagonal boron nitride $(\mathrm{BN}(\mathrm{h})$, particle size $1 \mu, 98 \%$, Sigma-Aldrich Co., Burlington, MA, USA) at $2 \mathrm{~g} / \mathrm{L}$ and cetyltrimethylammonium bromide (CTAB, 98\%, BDH Chemicals Ltd., Poole, UK) at $60 \mathrm{mg} / \mathrm{L}$. CTAB is a cationic surfactant used to disperse $\mathrm{BN}(\mathrm{h})$ particles in the plating bath.

Table 1. Composition of plating solution for Ni-W and Ni-W-BN(h) composite coating.

\begin{tabular}{cc}
\hline \multicolumn{3}{c}{ Plating Solution Composition } \\
\hline $\mathrm{NiSO}_{4} \cdot 6 \mathrm{H}_{2} \mathrm{O}$ & $0.06 \mathrm{~mol} / \mathrm{L}$ \\
$\mathrm{Na}_{2} \mathrm{WO}_{4} \cdot 2 \mathrm{H}_{2} \mathrm{O}$ & $0.14 \mathrm{~mol} / \mathrm{L}$ \\
$\mathrm{Na}_{3} \mathrm{C}_{6} \mathrm{H}_{5} \mathrm{O}_{7}$ & $0.4 \mathrm{~mol} / \mathrm{L}$ \\
$\mathrm{NH}_{4} \mathrm{Cl}$ & $0.5 \mathrm{~mol} / \mathrm{L}$ \\
$\mathrm{BN}(\mathrm{h})$ & $2 \mathrm{~g} / \mathrm{L}$ \\
$\mathrm{CTAB}$ & $60 \mathrm{mg} / \mathrm{L}$ \\
\hline
\end{tabular}


The electroplating process is stirred at $250 \mathrm{rpm}$ using a magnet. The anode is platinum titanium mesh, and the cathode is a low carbon steel plate $(33 \mathrm{~mm} \times 50 \mathrm{~mm}$ ) or a nodular cast iron piston ring. The Ni-W alloy and Ni-W-BN(h) composite coatings were prepared using an ADC35-20 DC power supply. The current density is $0.1 \mathrm{~A} / \mathrm{m}^{2}$, the plating temperature is $75{ }^{\circ} \mathrm{C}$, and the $\mathrm{pH}$ value is maintained at 8.5 . The electroplating time is $1 \mathrm{~h}$ and the coating thickness is about $33 \pm 3 \mu \mathrm{m}$. After plating, components were annealed at $600{ }^{\circ} \mathrm{C}$ for $1 \mathrm{~h}$ in a split hinge tube furnace (LINDBERG/BLUE-M-1200 ${ }^{\circ} \mathrm{C}$ SPLITHINGE), a Field Emission-Electron Probe Micro-Analyser (FE-EPMA, JXA-8530) was used to determine the composition of the coating.

The hardness of the coating was measured using a Vickers micro-hardness tester (HVS-1000), for which a load of $50 \mathrm{gf}$ was applied for $10 \mathrm{~s}$. Five points were measured for each coating, and the average value was used. A Bruker UMT TriboLab multi-function abrasion tester was used for a pin-on-disc reciprocating sliding test. The coatings were plated on a low-carbon steel sheet and rubbed with a pin (diameter $6 \mathrm{~mm}$ ) made of alumina. The experiment was carried out at a room temperature of $25 \pm 3{ }^{\circ} \mathrm{C}$ and a relative humidity $55 \pm 5 \%$. The test lasted for $5 \mathrm{~h}$ and used a load of $120 \mathrm{~N}$, a contact pressure of $4.24 \mathrm{Mpa}$, a stroke of $6 \mathrm{~mm}$, a sliding speed of $0.069 \mathrm{~m} / \mathrm{s}$, and a sliding distance of $1250 \mathrm{~m}$. The entire specimen and test contact area were completely immersed in SAE 10 W-40 oil. During the test, the friction coefficient was automatically recorded. The amount of wear was recorded by weighing the sample with a $0.01 \mathrm{mg}$ electronic balance, and this value is converted into a wear index in $\mathrm{mm}^{3} / \mathrm{Nm}$.

\subsection{Engine Performance Test}

This experiment used a 125 cc four-stroke single-cylinder air-cooled engine with an electronic fuel injection system. An eddy current engine dynamometer (AVL alpha40) was used with a system controller (AVL BME/EMCON Controller Series400) and a fuel consumption meter (AVL733S). The exhaust emissions were measured using an exhaust gas analyzer (Horiba MEXA-554J). A K-type thermocouple was mounted on the outer wall of the cylinder in the combustion chamber, near the spark plug, to measure the cylinder temperature. The thermocouple was affixed with heat-resistant tape to eliminate gaps that affect heat conduction and to reduce errors in the temperature measurement. A diagram of the engine dynamometer testing equipment is shown in Figure 1.

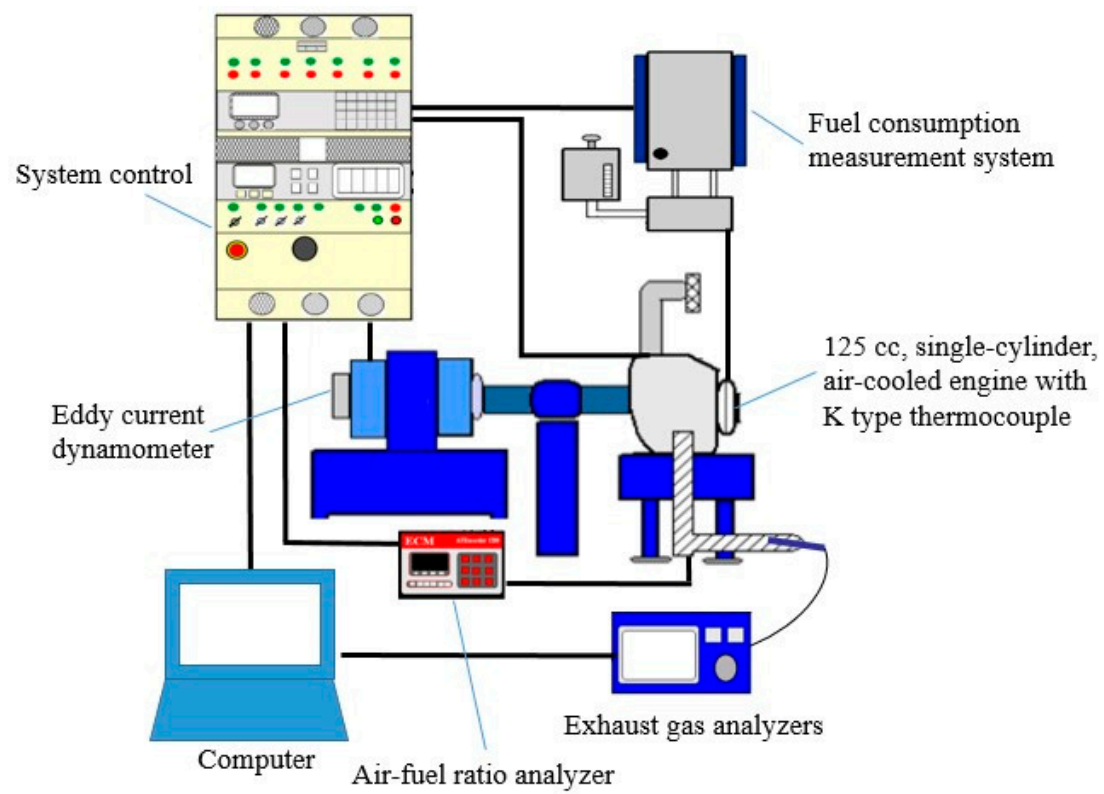

Figure 1. Schematic diagram of the engine dynamometer testing equipment. 
The torque $\mathrm{Tq}(\mathrm{N}-\mathrm{m})$ and the speed $\mathrm{N}(\mathrm{rpm})$ of the engine were measured using a dynamometer to calculate the break power $\dot{W}_{\mathrm{b}}(\mathrm{kW})$ using Equation (1):

$$
\dot{\mathrm{W}}_{\mathrm{b}}=\frac{\mathrm{T}_{\mathrm{q}} \cdot \mathrm{N}}{9549}
$$

The fuel mass flow rate $\dot{M}_{\mathrm{f}}(\mathrm{g} / \mathrm{h})$ was measured using a fuel consumption meter, and the brake specific fuel consumption BSFC (g/kW-h) is calculated using Equation (2):

$$
\mathrm{BSFC}=\frac{\dot{\mathrm{M}}_{\mathrm{f}}}{\dot{\mathrm{W}}_{\mathrm{b}}}
$$

The fuel conversion efficiency $\eta_{\mathrm{f}}(\%)$ is calculated using Equation (3):

$$
\eta_{\mathrm{f}}=\frac{1}{\mathrm{BSFC} \cdot \mathrm{Q}_{\mathrm{LHV}}}
$$

The brake mean effective pressure BMEP $(\mathrm{kPa})$ compares engines of various speeds and sizes. For a four-stroke cycle engine,

$$
\mathrm{BMEP}=\frac{4 \pi \cdot \mathrm{T}_{\mathrm{q}}}{\mathrm{V}_{\mathrm{d}}}
$$

where $Q_{L H V}$ is the low heating value of the fuel and $V_{d}$ is the exhaust gas volume [19].

An engine with coated piston rings was tested using a dynamometer for $50 \mathrm{~h}$. The radial wall thickness, width, and weight loss for the piston rings were measured using a vernier caliper and a $0.01 \mathrm{mg}$ electronic balance. The structure and morphology of the coated piston rings after the dynamometer test were observed using a scanning electron microscope (SEM, JSM-IT100).

\section{Results and Discussion}

\subsection{Mechanical Properties of the Coatings}

To determine the effect of the Ni-W alloy and Ni-W-BN(h) composite coatings plated onto the piston ring on the engine performance, the coatings were first plated on iron sheets, and the mechanical characteristics of the coating were determined. Table 2 shows that the hardness of low carbon steel is about $128 \mathrm{HV}$. After electroplating with Ni-W alloy and Ni-W-BN(h) composite coating and annealing for $1 \mathrm{~h}$, the hardness values increase to $1049 \mathrm{HV}$ and $989 \mathrm{HV}$, respectively. This increase depends on the W content of the coating.

\begin{tabular}{|c|c|c|c|c|c|c|}
\hline \multirow[b]{2}{*}{ Coating Type } & \multicolumn{3}{|c|}{ Coating Composition } & \multicolumn{3}{|c|}{ Mechanical Properties } \\
\hline & $\begin{array}{c}\mathrm{Ni} \\
(\mathrm{wt} . \%)\end{array}$ & $\begin{array}{c}W \\
(w t . \%)\end{array}$ & $\begin{array}{c}\text { BN(h) } \\
\text { (vol.\%) }\end{array}$ & $\begin{array}{l}\text { Hardness } \\
\text { (HV) }\end{array}$ & C.O.F & $\begin{array}{c}\text { Wear Index } \\
\left(10^{-6} \mathrm{~mm}^{3} / \mathrm{Nm}\right)\end{array}$ \\
\hline Fe Substrate & - & - & - & $128.3 \pm 1.1$ & $0.07 \pm 0.0034$ & $114.65 \pm 0.63$ \\
\hline $\mathrm{Ni}-\mathrm{W}$ & $59.4 \pm 0.9$ & $40.6 \pm 1.1$ & - & $1049.12 \pm 28.3$ & $0.11 \pm 0.0024$ & $17.8 \pm 0.97$ \\
\hline Ni-W-BN(h) & $56.5 \pm 0.2$ & $43.3 \pm 0.11$ & $5.13 \pm 0.6$ & $989.1 \pm 16.1$ & $0.10 \pm 0.0017$ & $10.4 \pm 0.65$ \\
\hline
\end{tabular}
As the $\mathrm{W}$ content of the coating increases, the hardness of the coating increases due to the solid solution strengthening effect [20].

Table 2. Mechanical properties of Fe substrate, Ni-W alloy, and Ni-W-BN(h) composite coating.

Figure 2 shows the average friction coefficient and wear index for Fe substrate, Ni-W alloy, and a Ni-W-BN(h) composite coating for a load of $120 \mathrm{~N}$ and lubrication using SAE $10 \mathrm{~W}-40$ oil. The Fe substrate has the lowest friction coefficient because its hardness value is the lowest, so the material cannot resist scratching from a counter body and incurs significant wear (Figure 3a). During the friction process, lubricating oil penetrates the scratch, 
producing hydrodynamic lubrication in some of the worn areas and reducing the friction coefficient. The mechanical properties of Ni-W alloy and Ni-W-BN(h) composite coatings are similar. During the friction process, the Ni-W matrix resists the counter body, so friction occurs because of adhesive wear due to material fatigue. The Ni-W-BN(h) composite coating contains boron nitride as self-lubricating particles (Figure 3b), and the solid lubricant properties significantly reduce the friction coefficient [21]. The results in Table 2 show that the Ni-W alloy and Ni-W-BN(h) composite coating are, respectively, 6.44 and 11.02 times more resistant to wear than the Fe substrate. The Ni-W-BN(h) composite coating is subject to the least wear.

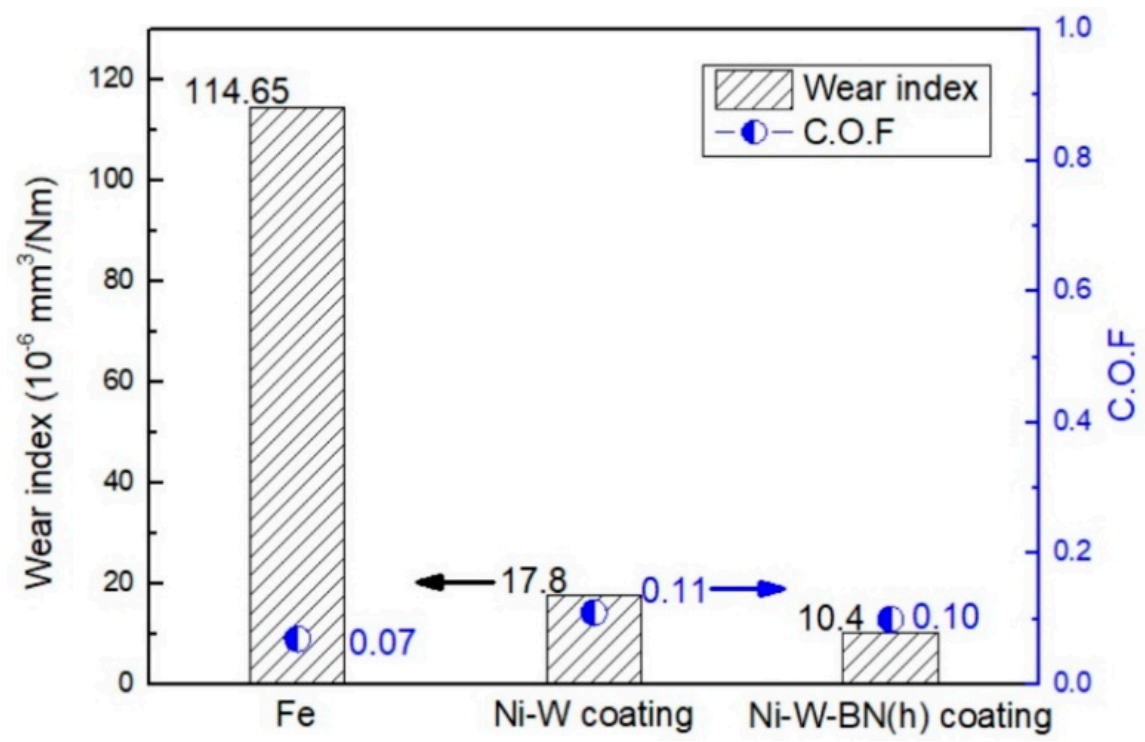

Figure 2. Comparison of C.O.F and wear index for Fe substrate, Ni-W alloy, and Ni-W-BN(h) composite coating using a load of $120 \mathrm{~N}$ and SAE $10 \mathrm{~W}-40$ engine oil as a lubricant.

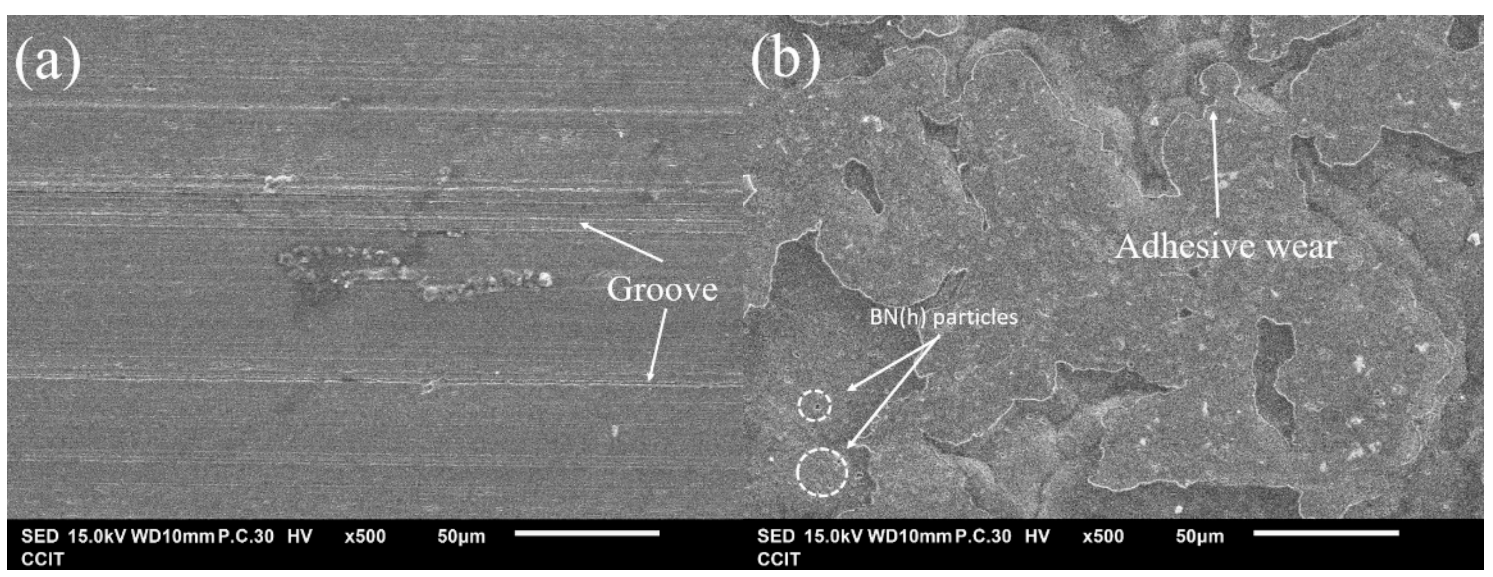

Figure 3. SEM images of the wear tracks for (a) Fe substrate and (b) Ni-W-BN(h) composite coating.

\subsection{Analysis of Engine Performance Characteristics}

Engine speed, load, and torque have a significant effect on performance. Friction between the piston ring, the piston skirt, and the cylinder wall is the main cause of energy loss in an engine, so losses due to engine wear are important.

To determine the effect of cylinder temperature $\left(\mathrm{T}_{\mathrm{sc}}\right)$ on engine characteristics, different operating parameters were used. The experimental data for different cylinder temperatures are fitted to a curve, and the average value is calculated. Using a commercially available Cr$\mathrm{N}$-sprayed piston ring in an engine as an example, Figure 4a shows the cylinder temperature $\left(\mathrm{T}_{\mathrm{SC}}\right)$ curve fitting diagram for 8 tests at a speed of $6000 \mathrm{rpm}$ and a throttle opening $\Psi=100 \%$. 
Using this cylinder temperature as the benchmark and sampling the BMEP, the fitting curve for cylinder temperature $\left(T_{s c}\right)$ to BMEP is produced (as shown in Figure $4 b$ ).
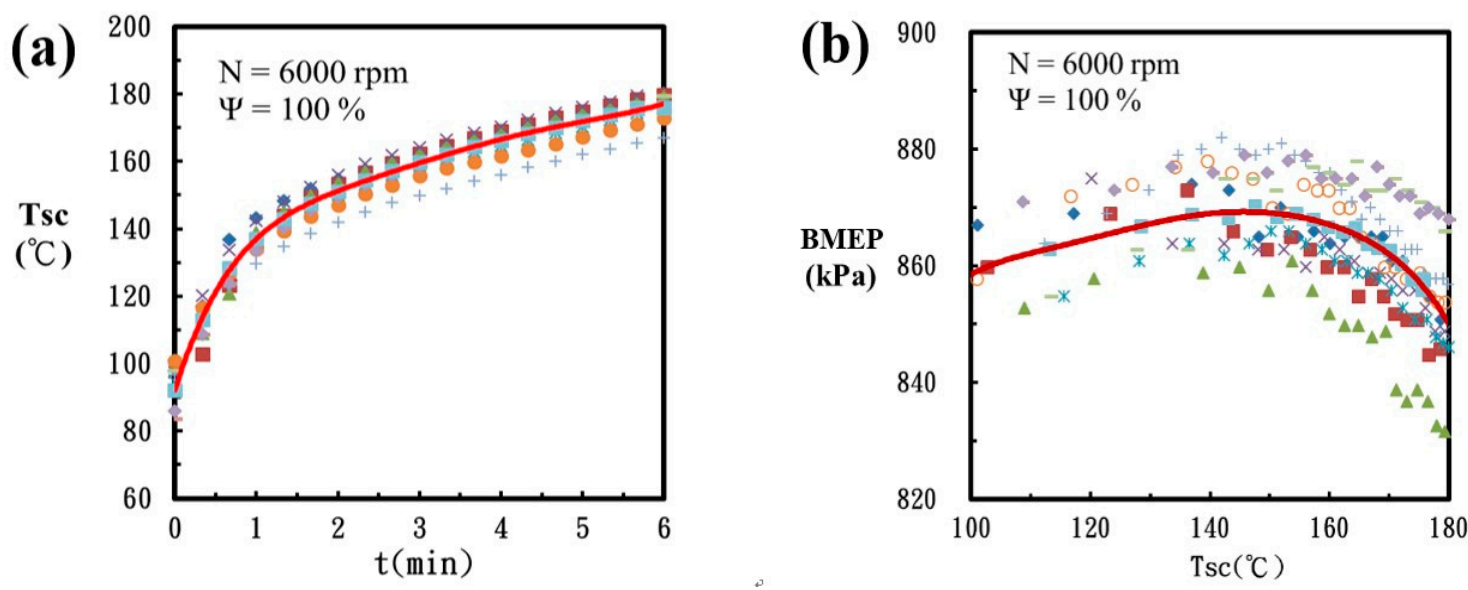

Figure 4. For an engine speed $\mathrm{N}=6000 \mathrm{rpm}$, throttle opening $\Psi=100 \%$ : $(\mathbf{a})$ cylinder temperature $\left(\mathrm{T}_{\mathrm{sc}}\right)$ fitting curve and (b) the fitting curve for the relationship between BMEP and cylinder temperature.

The experimental results show the effect of Fe substrate (no coating), Ni-W alloy, and $\mathrm{Ni}-\mathrm{W}-\mathrm{NB}(\mathrm{h})$ composite coated piston rings on engine characteristics for different speeds and throttle openings for an air-cooled engine. The brake mean effective pressure (BMEP) and the fuel conversion efficiency $\left(\eta_{f}\right)$ for the engine are determined, and the hydrocarbon (HC), carbon monoxide $(\mathrm{CO})$ concentrations, and exhaust gas temperature $\left(\mathrm{T}_{\mathrm{ep}}\right)$ are measured.

In general, the temperature of the engine body increases sharply under high load, so the engine can overheat. When the engine is under low load, the temperature of the engine body increases slowly, and excessive cooling reduces engine performance. Figure 5 shows the cylinder temperature $\left(\mathrm{T}_{\mathrm{sc}}\right)$ over time for Fe (No coating), Ni-W coating, and Ni-W-NB(h) composite coatings for piston rings at different engine speeds $(\mathrm{N}=5000,6000 \mathrm{rpm})$ and throttle openings $\Psi=75 \%$. The cylinder temperature gradually increases as the engine runs longer, and the cylinder temperature for the Ni-W-BN(h) composite coating increases faster under specific operating conditions. This shows that the Ni-W-BN(h) composite coating on the piston ring conducts heat more efficiently and quickly transfers heat from the combustion process from the piston ring to the cylinder wall, so the cylinder temperature increases faster.

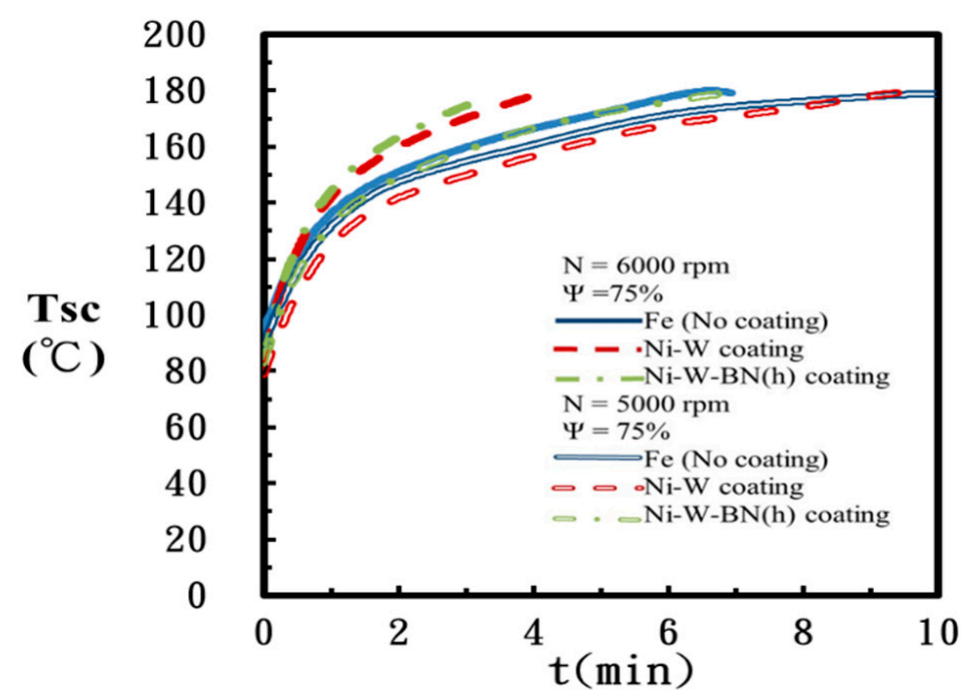

Figure 5. The cylinder temperature $\left(\mathrm{T}_{\mathrm{sc}}\right)$ for piston rings with different coatings at an engine speed $\mathrm{N}=6000,5000 \mathrm{rpm}$ and a throttle opening $\Psi=75 \%$. 
Brake mean effective pressure (BMEP) is affected by multiple factors, such as engine intake and exhaust efficiency, fuel injection volume, ignition timing, frictional loss, and pumping loss. This study tests an electronic control unit (ECU) at constant settings for the dynamometer. The engine speed $\mathrm{N}=5000$ and $6000 \mathrm{rpm}$, the throttle opening $\Psi=25 \%$ and $75 \%$, and BMEP is calculated using the cylinder temperature $\left(\mathrm{T}_{\mathrm{sc}}\right)$.

Figure 6 shows the engine dynamometer test result for Fe (No coating), Ni-W coating, and Ni-W-NB(h) composite coating for a piston ring using a throttle opening $\Psi=25 \%$. The results show that the frictional loss in the engine at low throttle opening increases as speed increases, and the intake volume efficiency decreases as speed increases. An increase in engine speed results in a decrease in BMEP. However, an engine has a large volumetric efficiency at medium/high throttle openings, with little effect compared with pumping loss and friction loss. At the higher engine speed ( $\mathrm{N}=6000 \mathrm{rpm})$, fuel supply is increased, and the indicated power output is greater, so BMEP is increased (Figure 7).

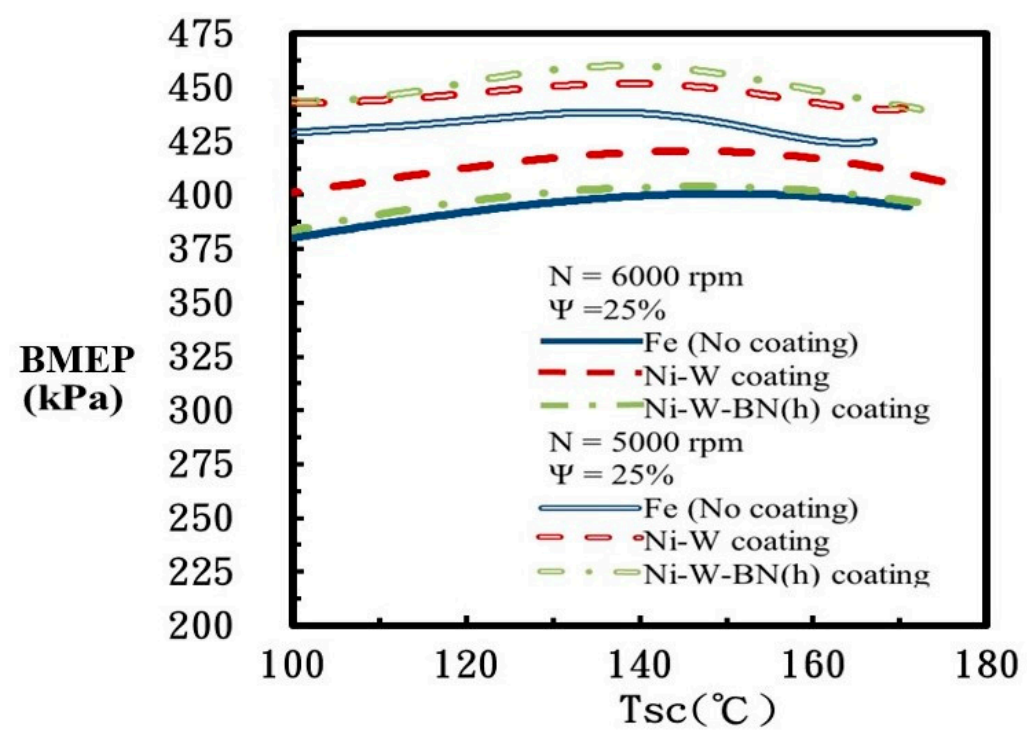

Figure 6. BMEP for different cylinder temperatures $\left(\mathrm{T}_{\mathrm{sc}}\right)$ for an engine with a coated piston ring at engine speeds $\mathrm{N}=6000$ and $5000 \mathrm{rpm}$ and a throttle opening $\Psi=25 \%$.

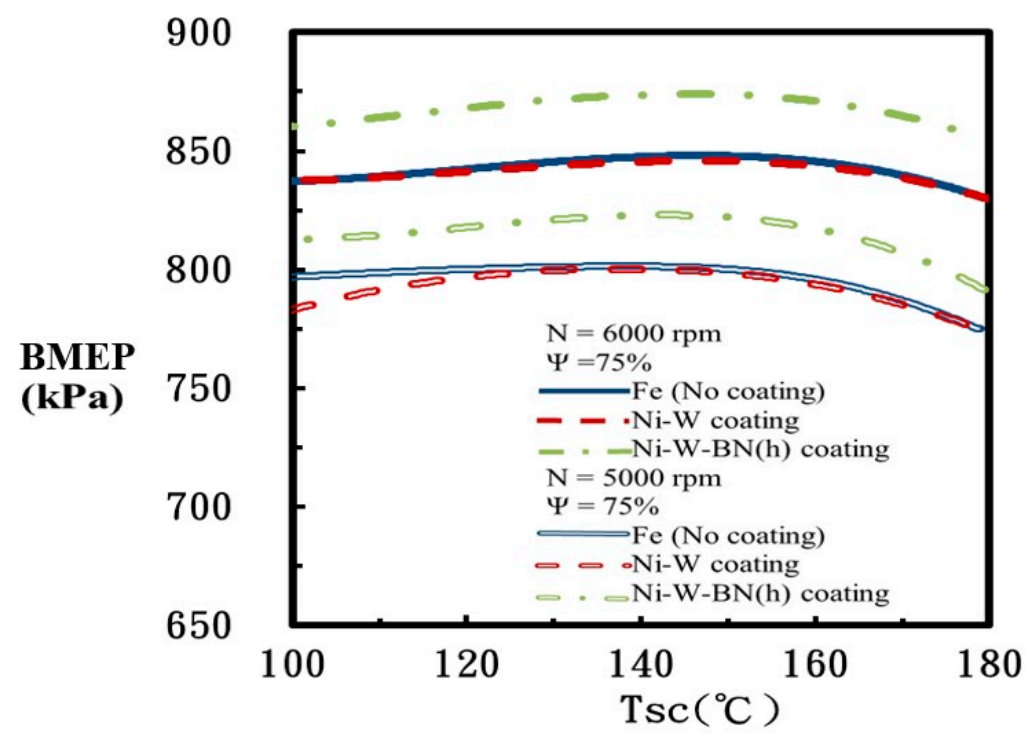

Figure 7. BMEP for different cylinder temperatures $\left(\mathrm{T}_{\mathrm{sc}}\right)$ for an engine with a coated piston ring at engine speeds $N=6000$ and $5000 \mathrm{rpm}$ and a throttle opening $\Psi=75 \%$. 
At small throttle openings, the pumping loss is larger because there is a large negative pressure at the intake manifold, and intake efficiency is low. If the ECU fuel-air ratio is small (small fuel injection), the BMEP is low. At large throttle openings, the amount of injected fuel increases because of increased air intake. Pumping loss also has less effect, so BMEP is greater. The curve for BMEP for different cylinder temperatures $\left(\mathrm{T}_{\mathrm{SC}}\right)$ shows that the engine achieves the best working temperature before the cylinder temperature gradually increases and reaches the optimal BMEP peak. A gradual increase in fuel vaporization increases the amount of energy that is converted into braking power, and BMEP increases as the cylinder temperature increases. At the optimal BMEP, a slightly thicker oil gas $(\psi>1)$ volatilizes at a higher cylinder temperature, so the engine intake volumetric efficiency decreases and BMEP is reduced.

In terms of the different coatings, at an engine speed of $6000 \mathrm{rpm}$ and a throttle opening $\Psi=25 \%$ and $\Psi=75 \%$, the respective BMEP peaks for Fe (No coating) are $402.2 \mathrm{kPa} / 143.8^{\circ} \mathrm{C}$ and $848.5 \mathrm{kPa} / 152.8^{\circ} \mathrm{C}$, the respective BMEP peaks for the Ni-W coating are $421.3 \mathrm{kPa} / 141.9^{\circ} \mathrm{C}$ and $847.7 \mathrm{kPa} / 155.3^{\circ} \mathrm{C}$ and the respective BMEP peaks for $\mathrm{Ni}-\mathrm{W}-\mathrm{NB}(\mathrm{h})$ composite coating are $406.2 \mathrm{kPa} / 150.3^{\circ} \mathrm{C}$ and $874.9 \mathrm{kPa} / 132.7^{\circ} \mathrm{C}$. The $\mathrm{Ni}-\mathrm{W}-\mathrm{BN}(\mathrm{h})$ composite coating performs best, and the best operating temperature for the engine is about $132{ }^{\circ} \mathrm{C}$ to $150{ }^{\circ} \mathrm{C}$.

At an engine speed of $5000 \mathrm{rpm}$ and a throttle opening $\Psi=25 \%$ and $\Psi=75 \%$, the respective BMEP peaks for Fe (No coating) are $440 \mathrm{kPa} / 141{ }^{\circ} \mathrm{C}$ and $803 \mathrm{kPa} / 138{ }^{\circ} \mathrm{C}$, the respective $\mathrm{BMEP}$ peaks for $\mathrm{Ni}-\mathrm{W}$ coating are $456.5 \mathrm{kPa} / 139.6{ }^{\circ} \mathrm{C}$ and $802.3 \mathrm{kPa} / 147.9{ }^{\circ} \mathrm{C}$ and the respective BMEP peaks for $\mathrm{Ni}-\mathrm{W}-\mathrm{NB}(\mathrm{h})$ composite coating are $462.1 \mathrm{kPa} / 138.8^{\circ} \mathrm{C}$ and $822.5 \mathrm{kPa} / 149.5^{\circ} \mathrm{C}$. The Ni-W-BN(h) composite coating performs best, and the optimal operating temperature for the engine is about $139^{\circ} \mathrm{C}$ to $150{ }^{\circ} \mathrm{C}$.

Fuel conversion efficiency $\left(\eta_{\mathrm{f}}\right)$ is an efficiency index that measures the engine's ability to convert energy per unit of fuel calorific value into output work and measures the degree to which the engine saves energy. Figure 8 shows the fuel conversion efficiency $\left(\eta_{f}\right)$ for engines for which the piston ring is $\mathrm{Fe}$ (No coating) or has a Ni-W coating or a Ni-W-NB(h) composite coating for a throttle opening $\Psi=75 \%$. If the throttle opening is large, the intake air volume is increased, and the energy that is generated by the fuel is increased. The effect of pumping losses and frictional losses is small, so the braking power of the engine is increased.

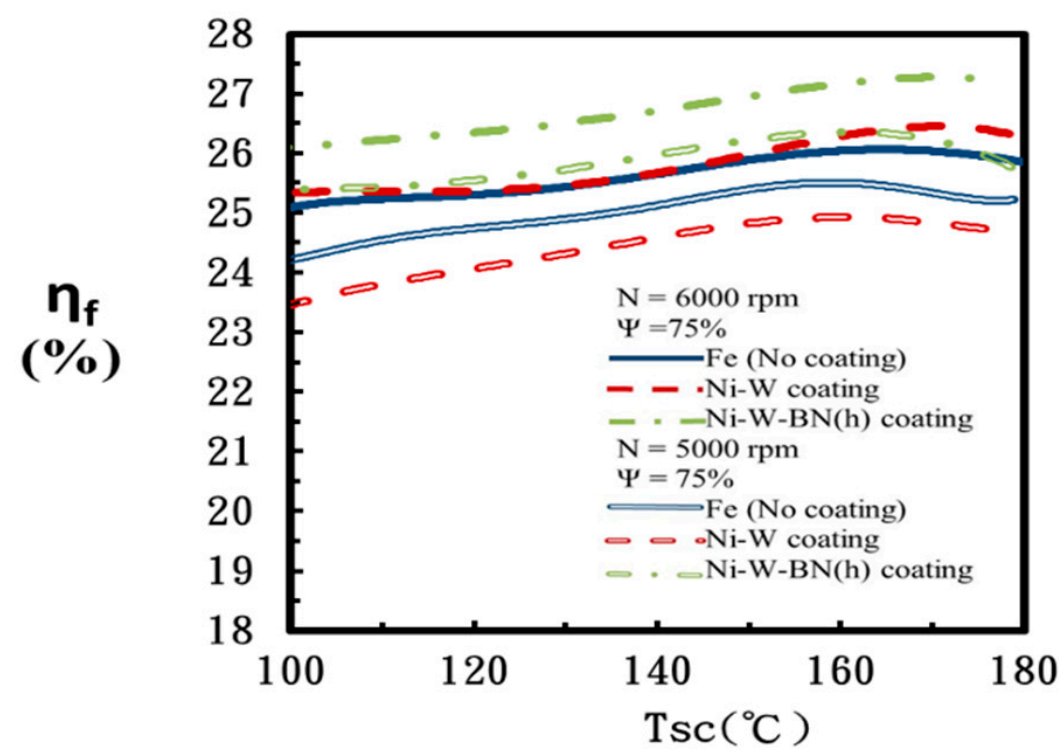

Figure 8. Fuel conversion efficiency $\left(\eta_{f}\right)$ at different cylinder temperatures $\left(T_{s c}\right)$ for an engine with a coated piston ring at speeds $\mathrm{N}=6000$ and $5000 \mathrm{rpm}$ and a throttle opening $\Psi=75 \%$. 
For large throttle openings, the fuel conversion efficiency $\left(\eta_{\mathrm{f}}\right)$ at an engine speed $\mathrm{N}=6000 \mathrm{rpm}$ is better, so performance increases. For small throttle openings ( $\Psi=25 \%$, the pumping loss is increased because there is a high negative pressure at the intake manifold. The intake and exhaust efficiency are also reduced at high engine speeds, so there are greater pumping losses. For small throttle openings, the fuel conversion efficiency $\left(\eta_{\mathrm{f}}\right)$ at an engine speed $\mathrm{N}=5000 \mathrm{rpm}$ increases, and performance increases (Figure 9).

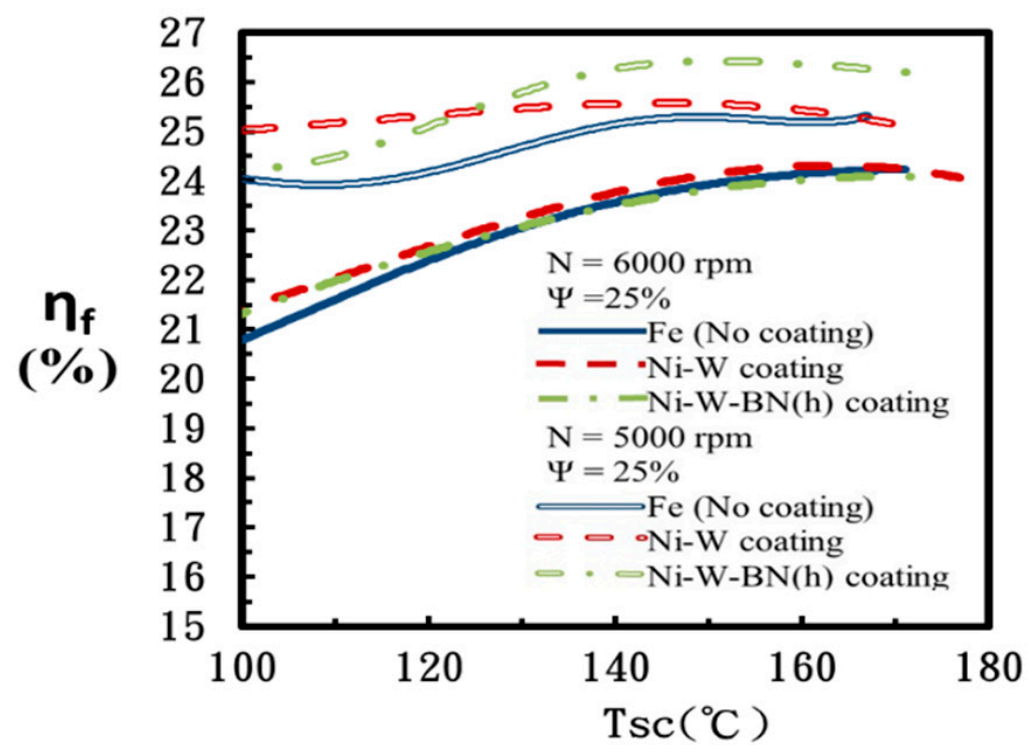

Figure 9. Fuel conversion efficiency $\left(\eta_{\mathrm{f}}\right)$ at different cylinder temperatures (Tsc) for an engine with a coated piston ring at speeds $\mathrm{N}=6000$ and $5000 \mathrm{rpm}$ and a throttle opening $\Psi=25 \%$.

In terms of the different coatings, at an engine speed of $6000 \mathrm{rpm}$ and a throttle opening $\Psi=25 \%$ and $\Psi=75 \%$, the peak fuel conversion efficiency $\left(\eta_{\mathrm{f}}\right)$ for Fe (No coating) is $24.3 \% / 162.1{ }^{\circ} \mathrm{C}$ and $26.1 \% / 163.1{ }^{\circ} \mathrm{C}$, the peak fuel conversion efficiency $\left(\eta_{\mathrm{f}}\right)$ for $\mathrm{Ni}-\mathrm{W}$ coating is $24.5 \% / 160.1^{\circ} \mathrm{C}$ and $26.5 \% / 170.7$ and the fuel conversion efficiency $\left(\eta_{\mathrm{f}}\right)$ for the $\mathrm{Ni}-\mathrm{W}-\mathrm{NB}(\mathrm{h})$ composite coating is $24.2 \% / 169.9^{\circ} \mathrm{C}$ and $27.3 \% / 170.5^{\circ} \mathrm{C}$. The fuel conversion efficiency $\left(\eta_{\mathrm{f}}\right)$ is greatest for a Ni-W-BN $(\mathrm{h})$ composite coating, and the best working temperature for the engine is $169^{\circ} \mathrm{C}$ to $170{ }^{\circ} \mathrm{C}$.

At an engine speed of $5000 \mathrm{rpm}$ and a throttle opening $\Psi=25 \%$ and $\Psi=75 \%$, the peak fuel conversion efficiency $\left(\eta_{\mathrm{f}}\right)$ for Fe (No coating) is $25.6 \% / 164.2{ }^{\circ} \mathrm{C}$ and $25.5 \% / 160.4{ }^{\circ} \mathrm{C}$, the peak fuel conversion efficiency $\left(\eta_{\mathrm{f}}\right)$ for the $\mathrm{Ni}-\mathrm{W}$ coating is $25.4 \% / 145.5{ }^{\circ} \mathrm{C}$ and $24.9 \% / 161.4{ }^{\circ} \mathrm{C}$ and the peak fuel conversion efficiency $\left(\eta_{\mathrm{f}}\right)$ for the Ni-W-NB(h) composite coating is $26.7 \% / 159.9^{\circ} \mathrm{C}$ and $26.3 \% / 164.4^{\circ} \mathrm{C}$. The Ni-W-BN(h) composite coating gives the greatest fuel conversion efficiency $\left(\eta_{\mathrm{f}}\right)$, and the best working temperature for the engine is $150{ }^{\circ} \mathrm{C}$ to $168^{\circ} \mathrm{C}$.

For all operating conditions, the Ni-W-BN(h) composite coating performs best, and the highest BMEP is produced at a cylinder temperature of $132{ }^{\circ} \mathrm{C}$ to $150{ }^{\circ} \mathrm{C}$. The best fuel conversion efficiency $\left(\eta_{\mathrm{f}}\right)$ is achieved between $150{ }^{\circ} \mathrm{C}$ and $170{ }^{\circ} \mathrm{C}$. These figures show the potential benefits of nickel-based self-lubricating particulate composite coatings on piston rings.

Coated piston rings were installed in an engine for a dynamometer test for $50 \mathrm{~h}$. Figure 10 shows the wear loss percentage for the piston rings in terms of dimensions and weight before and after the test. The results show that a piston ring plated with Ni-W-BN(h) is subject to the smallest decrease in radial thickness, width and weight and shows the best wear resistance. A piston ring that is plated with $\mathrm{Ni}-\mathrm{W}$ is subject to greater wear, and the piston ring without a coating has the worst wear resistance. This result is consistent with the results for the lubrication friction experiment in Section 3.1. 


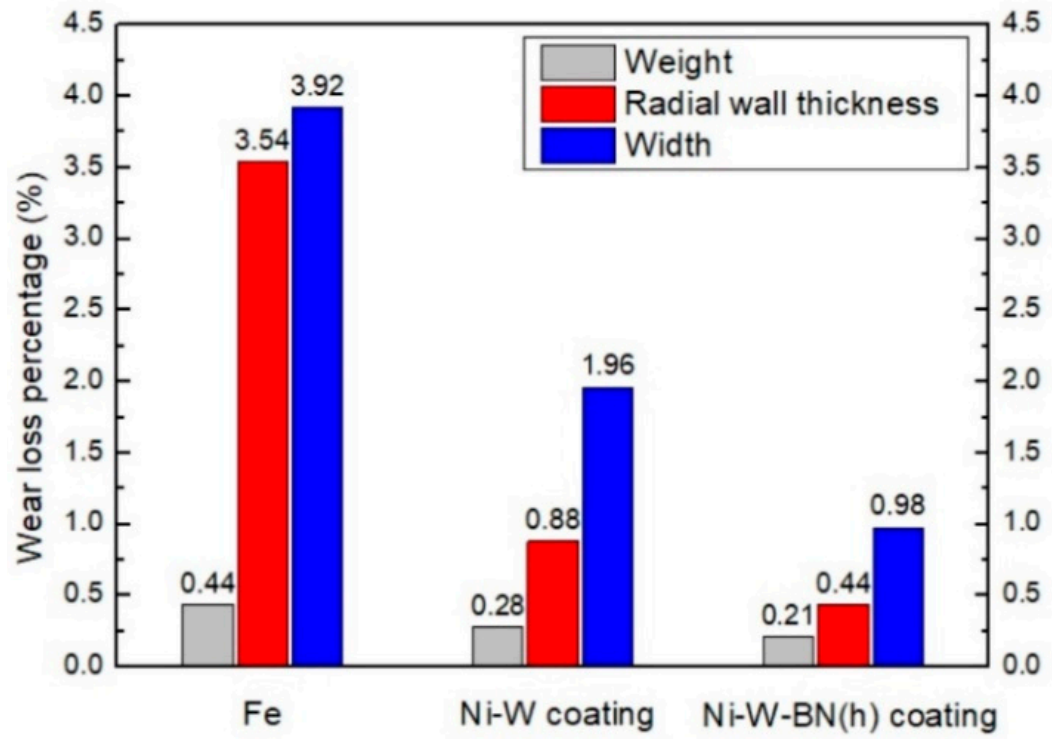

Figure 10. Wear loss percentage for a coated piston ring after engine testing for $50 \mathrm{~h}$.

Figure 11 shows an SEM image of a piston ring plated with Ni-W-BN(h) after $50 \mathrm{~h}$ of dynamometer testing. The coating is intact and has no visible cracks, and $\mathrm{BN}(\mathrm{h})$ particles are dispersed in the coating. The contact surface with the cylinder wall has only a few scratch grooves, some accumulated debris, and good wear resistance.

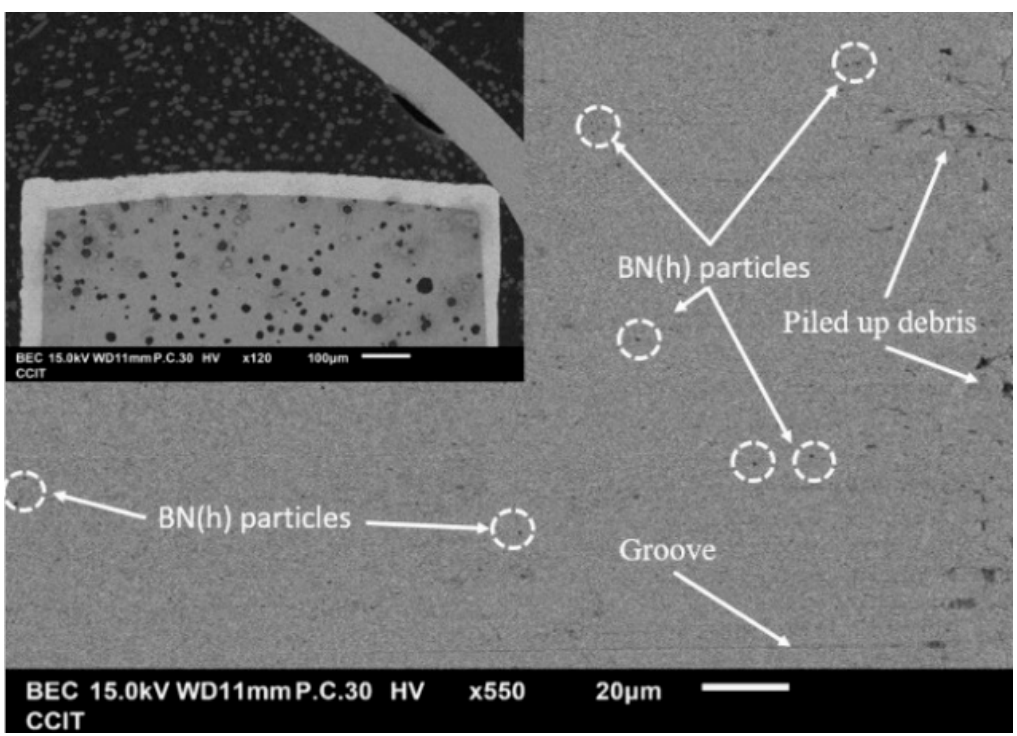

Figure 11. SEM image of cross-section and surface morphology (contact with cylinder wall) for a piston ring plated with $\mathrm{Ni}-\mathrm{W}-\mathrm{BN}(\mathrm{h})$ after engine testing for $50 \mathrm{~h}$.

The piston ring coated with $\mathrm{Ni}-\mathrm{W}-\mathrm{BN}(\mathrm{h})$ gives better $\mathrm{BMEP}$ because it is more resistant to wear. This ensures that there is an almost constant clearance between the piston ring and the cylinder wall. The piston ring with a Ni-W-BN $(h)$ coating exhibits the least wear after $50 \mathrm{~h}$ of dynamometer testing (Figure 10) because there is a better seal between the piston ring and the cylinder wall. Therefore, the pressure inside the combustion chamber is greater under most operating conditions. The 50-h engine dynamometer test shows that the piston ring with the $\mathrm{Ni}-\mathrm{W}-\mathrm{BN}(\mathrm{h})$ coating gives the highest average BMEP (Table 3 ). 
Table 3. Engine performance characteristics for Fe substrate and piston rings coated with Ni-W alloy and $\mathrm{Ni}-\mathrm{W}-\mathrm{BN}(\mathrm{h})$.

\begin{tabular}{cccc}
\hline Coating Type & BMEP (kPa) & $\boldsymbol{\eta}_{\mathbf{f}}(\mathbf{\%})$ & $\dot{\mathbf{M}}_{\mathbf{f}}(\mathbf{g} / \mathbf{h})$ \\
\hline Fe Substrate & 669 & 25.39 & 2600 \\
Ni-W & 706.2 & 25.47 & 2608 \\
Ni-W-BN(h) & 718.3 & 26.01 & 2590 \\
\hline
\end{tabular}

Table 3 also shows that a piston ring that is coated with Ni-W-BN(h) gives greater fuel conversion efficiency $\left(\eta_{f}\right)$ because Ni-W-BN(h) includes BN(h) self-lubricating particles, so frictional losses are reduced. The increase in BMEP results in greater horsepower output and better fuel conversion efficiency.

\subsection{Engine Exhaust Analysis}

Spark Ignition Engines (SI Engines) generate power via a chemical combustion reaction involving gasoline. If gasoline is completely burned, the products are carbon dioxide and water. If the ratio of gasoline to air in the cylinder is not optimal, there is incomplete combustion, and emissions include polluting hydrocarbons (HC) and carbon monoxide (CO). If the oil-to-gas ratio in the cylinder is too rich or there is insufficient oxygen to generate a combustion reaction, a small air-fuel ratio (AFR) produces incomplete combustion. Unburned gasoline is a source of HC in exhaust emissions, CO is generated when fuel is burned, and oil and gas molecules do not combine with enough oxygen atoms. This occurs when fuel atomization is poor, so dense fuel burns and the air-to-fuel mixture is uneven. This study tests the engine at an ideal air-fuel equivalence ratio of $\lambda \approx 1$ for $50 \mathrm{~h}$ to compare the effect of differently coated piston rings on exhaust-borne pollutants and exhaust temperature.

Figure 12 shows the average value for $\mathrm{HC}$ in exhaust gas that is emitted at all throttle openings $(\Psi)$ by engines that use different coatings for piston rings. Compared to $\mathrm{Fe}$ Substrate (No coating) (42.5 ppm), Ni-W coating HC (42.51 ppm) produces $0.1 \mathrm{ppm}$ more particles, and emissions are increased by $0.23 \%$. The Ni-W-BN(h) composite coating produces an average (41.1 ppm) reduction of $2.03 \mathrm{ppm}$, and emissions are reduced by $3.29 \%$.

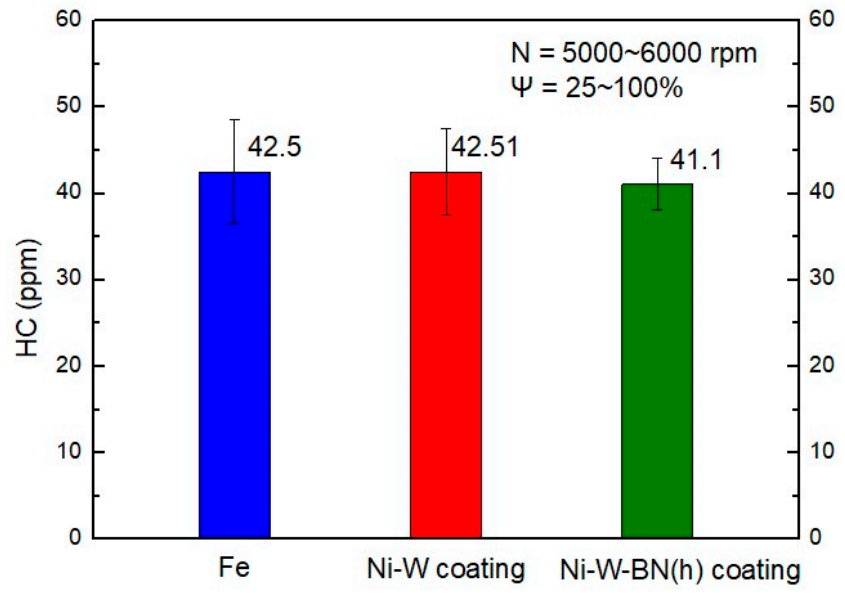

Figure 12. Average value for exhaust hydrocarbons $(\mathrm{HC})$ for different piston ring coatings at all throttle openings ( $\Psi)$.

Figure 13 shows the average values for carbon monoxide (CO) in the exhaust gas at all throttle openings ( $\Psi$ ) for engines that use different coatings for piston rings. Compared to Fe Substrate (No coating) (3.12 vol.\%), the CO emission (3.16 vol.\%) for Ni-W coating are 0.04 vol. $\%$ higher, and the emissions are increased by $1.28 \%$. The Ni-W-BN(h) composite coating gives an average $(2.89 \mathrm{vol} . \%)$ reduction of $0.12 \mathrm{vol} . \%$, and emissions are reduced by $7.37 \%$, which is the greatest improvement. 


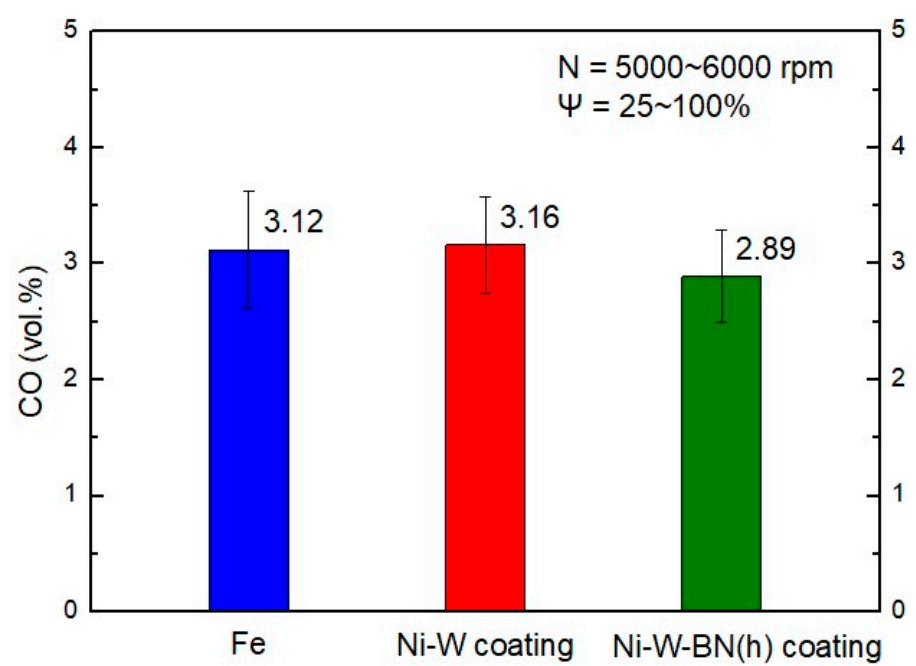

Figure 13. Average value for exhaust carbon monoxide $(\mathrm{CO})$ for different piston ring coatings at all throttle openings $(\Psi)$.

A Ni-W coating has higher wear resistance than Fe substrate, but its lack of lubrication increases fuel consumption. The total fuel mass flow rate $\left(\dot{M}_{f}\right)$ for different piston rings is listed in Table 3. A piston ring that is plated with $\mathrm{Ni}-\mathrm{W}$ alloy produces a slightly higher average fuel consumption than a Fe substrate piston ring, so $\mathrm{HC}$ and $\mathrm{CO}$ emissions are increased, but not significantly. A piston ring coated with $\mathrm{Ni}-\mathrm{W}-\mathrm{BN}(\mathrm{h})$ gives the lowest fuel mass flow rate and increases wear resistance because of its self-lubricating properties; the concentration of $\mathrm{HC}$ and $\mathrm{CO}$ in the exhaust gas is the least, so exhaust pollution is reduced.

Figure 14 shows the average value for the exhaust temperature at all throttle openings

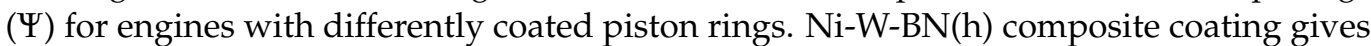
the lowest exhaust temperature, followed by Ni-W coating. In comparison to Fe Substrate (No coating) $\left(619.1^{\circ} \mathrm{C}\right)$, the exhaust gas temperature $\left(613.8^{\circ} \mathrm{C}\right)$ for $\mathrm{Ni}-\mathrm{W}$ coating is $5.3^{\circ} \mathrm{C}$ lower, which is a decrease of $0.88 \%$. The average $\left(608.6^{\circ} \mathrm{C}\right)$ for $\mathrm{Ni}-\mathrm{W}-\mathrm{BN}(\mathrm{h})$ composite coating is $10.5^{\circ} \mathrm{C}$ lower, which is a decrease of $1.69 \%$. A piston ring with a Ni-W-BN(h) composite coating produces the least heat loss, so the engine has the best energy conversion efficiency, and this coating is eminently suited to use in low-heat rejection engines.

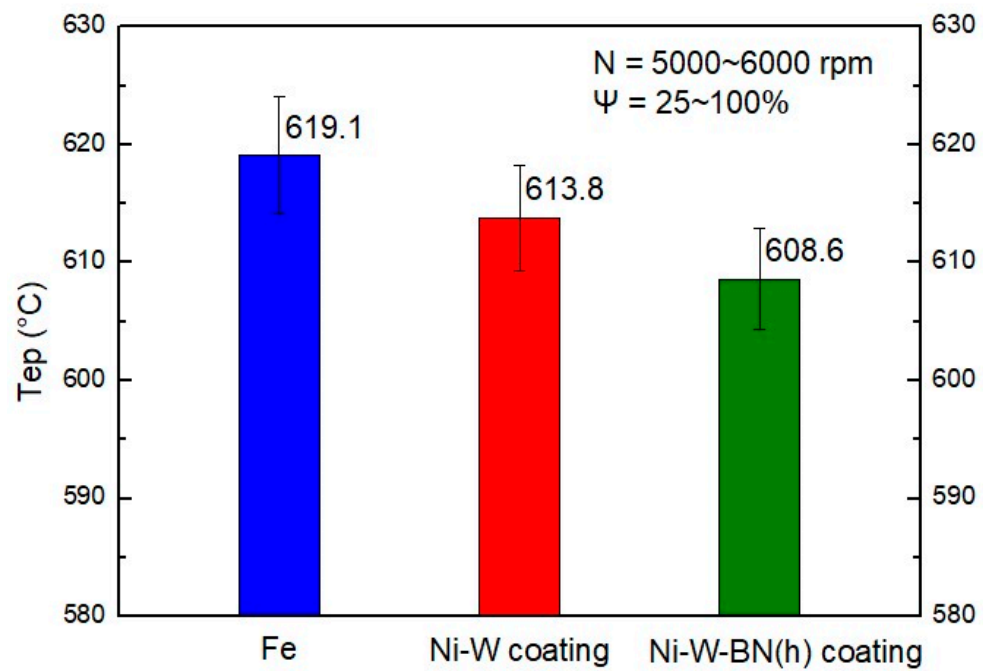

Figure 14. Average value for exhaust temperature for differently coated piston ring engines at all throttle openings $(\Psi)$. 


\title{
4. Conclusions
}

- The results of the friction test show that a Ni-W alloy and a Ni-W-BN(h) composite coating protect the substrate material. Compared with the Fe substrate, the Ni-W alloy and $\mathrm{Ni}-\mathrm{W}-\mathrm{BN}(\mathrm{h})$ composite coating are respectively 6.44 and 11.02 times more resistant to wear. The coatings are applied to the piston rings, and the results of an engine dynamometer test show that the Ni-W alloy and the Ni-W-BN(h) composite coating have good wear resistance;

- $\quad \mathrm{Ni}-\mathrm{W}-\mathrm{BN}(\mathrm{h})$ composite coating contains boron nitride self-lubricating particles, reducing frictional energy losses under mixing or boundary lubrication conditions. At the optimum cylinder temperature, the engine produces more BMEP under all operating conditions, and power output increases and fuel consumption is reduced, so fuel conversion efficiency $\left(\eta_{\mathrm{f}}\right)$ is increased;

- For engines that use piston rings with a Ni-W-BN(h) composite coating, the optimal cylinder temperature range that gives the best BMEP is between $132{ }^{\circ} \mathrm{C}$ and $150{ }^{\circ} \mathrm{C}$. The best fuel conversion efficiency $\left(\eta_{\mathrm{f}}\right)$ is achieved at a cylinder temperature of between $150{ }^{\circ} \mathrm{C}$ and $170{ }^{\circ} \mathrm{C}$. Therefore, the best BMEP and fuel conversion efficiency $\left(\eta_{\mathrm{f}}\right)$ is achieved at a cylinder temperature of about $150^{\circ} \mathrm{C}$. This is crucial information for the design of an engine;

- A piston ring with $\mathrm{Ni}-\mathrm{W}-\mathrm{BN}(\mathrm{h})$ composite coating piston ring produces the least hydrocarbons (HC) and carbon monoxide (CO). Compared with an engine that uses an uncoated piston ring, the exhaust temperature $\left(T_{e p}\right)$ is reduced by $1.69 \%$, so it is eminently suited to use in low-heat rejection engines.

\begin{abstract}
Author Contributions: Methodology, C.-C.C. and H.-B.D.; investigation, C.-C.C., P.-C.H. and H.-B.D.; resources, P.-C.H.; writing-original draft preparation, C.-C.C. and P.-C.H.; writing-review and editing, C.-C.C. and P.-C.H.; supervision, C.-C.C.; project administration, P.-C.H. All authors have read and agreed to the published version of the manuscript.
\end{abstract}

Funding: This research is funded by grant no. M.O.S.T. No. 108-2218-E-606-002-MY2 from the Taiwan Ministry of Science and Technology. The authors are grateful for the financial support for this study.

Acknowledgments: Thanks to Kung-Hsu Hou and Ming-Der Ger of NDU CCIT for support with electrodeposition and equipment for the lubrication friction experiment.

Conflicts of Interest: The authors declare no conflict of interest.

\section{References}

1. Pulkrabek, W.W. Engineering fundamentals of the internal combustion engine. Prentice Hall 2004, 126, 69-438.

2. Rosenberg, R.C. General Friction Considerations for Engine Design; SAE Technical Paper; SAE International: Warrendale, PA, USA, 1982

3. Allmaier, H.; Knauder, C.; Salhofer, S.; Reich, F.M.; Schalk, E.; Ofner, H.; Wagner, A. An experimental study of the load and heat influence from combustion on engine friction. Int. J. Engine Res. 2016, 17, 347-353. [CrossRef]

4. Sandoval, D.; Heywood, J.B. An improved friction model for spark-ignition engines. SAE Trans. 2003, 112, 1041-1052.

5. Taraza, D.; Henein, N.A.; Ceausu, R.; Bryzik, W. Engine Friction Model for Transient Operation of Turbocharged, Common Rail Diesel Engines; SAE Technical Paper; SAE International: Warrendale, PA, USA, 2007.

6. Patton, K.J.; Nitschke, R.G.; Heywood, J.B. Development and Evaluation of a Friction Model for Spark-Ignition Engines. SAE Trans. 1989, 98, 1441-1461.

7. Richardson, D.E. Review of power cylinder friction for diesel engines. J. Eng. Gas Turbines Power 2000, 122, 506-519. [CrossRef]

8. Vinoth, I.S.; Detwal, S.; Umasankar, V.; Sarma, A. Tribological studies of automotive piston ring by diamond-like carbon coating. Tribol.-Mater. Surf. Interfaces 2019, 13, 31-38. [CrossRef]

9. Andersson, P.; Tamminen, J.; Sandström, C.-E. Piston Ring Tribology: A Literature Survey; VTT Technical Research Centre of Finland: Espoo, Finland, 2002.

10. Malathi, M.; Mabel, J.H.; Rajendran, R.; Gowrishankar, N. Ni-P Composite Plating on Piston Ring for Improved Wear Performance; SAE Technical Paper; SAE International: Warrendale, PA, USA, 2017.

11. Karamış, M.; Yıldızlı, K.; Çakırer, H. An evaluation of surface properties and frictional forces generated from Al-Mo-Ni coating on piston ring. Appl. Surf. Sci. 2004, 230, 191-200. [CrossRef]

12. Hirapara, B.B.; Patel, V.C.; Sharma, H.R.; Ranjan, R.K.; Patel, P. A Technical research on piston ring coating of single cylinder four stroke SI engine fuelled with compressed natural gas. Int. J. Sci. Technol. Eng. 2015, 1, $270-275$. 
13. Ghouse, M. Wear Characteristics of Sediment Co-Deposited Nickel-SiC Composite Coatings. Met. Finish. 1984, 82, 33-37.

14. Liue, C.Y.; Wang, J.W.; Peng, Y.M.; Chen, H.J.; Shen, J.H. Ni-SiC Composite Plating. MRL Bull. Res. Dev. 1990, 4, 31-34.

15. Tański, T.; Snopiński, P.; Pakieła, W. Structure and properties of ultra fine grained aluminium alloys after laser surface treatment: Struktur und Eigenschaften von ultrafeinkörnigen Aluminiumlegierungen nach Laseroberflächenbehandlung. Mater. Und Werkst. 2016, 47, 419-427. [CrossRef]

16. Allahyarzadeh, M.; Aliofkhazraei, M.; Rezvanian, A.; Torabinejad, V.; Rouhaghdam, A.S. Ni-W electrodeposited coatings: Characterization, properties and applications. Surf. Coat. Technol. 2016, 307, 978-1010. [CrossRef]

17. Bąkowski, H. Wear mechanism of spheroidal cast iron piston ring-aluminum matrix composite cylinder liner contact. Arch. Metall. Mater. 2018, 63, 481-490.

18. Mahathanabodee, S.; Palathai, T.; Raadnui, S.; Tongsri, R.; Sombatsompop, N. Dry Sliding Wear Behavior of SS316L Composites Containing h-BN and MoS2 Solid Lubricants. Wear 2014, 316, 37-48. [CrossRef]

19. Heywood, J.B. Combustion Engine Fundamentals, 1st ed.; McGraw-Hill Education: New York, NY, USA, 1988 ; pp. $50-53$.

20. Huang, P.C.; Chou, C.C.; Hsu, L.S. Preparation and tribological research of the electrodeposited Ni W alloy coatings for piston ring application. Surf. Coat. Technol. 2021, 411, 126980. [CrossRef]

21. Sangeetha, S.; Kalaignan, G.P. Tribological and electrochemical corrosion behavior of Ni-W/BN (hexagonal) nano-composite coatings. Ceram. Int. 2015, 41, 10415-10424. [CrossRef] 